\title{
Comparative study of proximate, phytochemical and mineral compositions of edible plant fruits/seeds from Nigerian rainforest
}

\author{
Michael C. DIKE * and E. AHAMEFULA NNAMDI \\ Department of Forestry and Environmental Management, Michael Okpara University of Agriculture, \\ Umudike, Nigeria. \\ *Corresponding author; E-mail: michael.dike@ymail.com; (+234)08064349125, (+234)08063967542
}

\begin{abstract}
Proximate, phytochemical and mineral compositions of Aframomum melegueta, Dacryodes edulis, Dialium guineense, Gambeya albida and Garcinia kola were studied at Umudike, Nigeria. Fruits of these five plant species were collected in separately labeled and marked polythene bags at the rainforest at Umudike, Nigeria. The edible parts were separated from the non edible parts. The edible parts were put in labeled envelopes and dried in an oven set at $65{ }^{\circ} \mathrm{C}$ for 24 hours. The proximate, phytochemical and mineral compositions of each sample were analyzed at the laboratory of the Department of Chemistry, University of Agriculture, Umudike. There were differences between species in the percent carbohydrate, ash, protein and fibre contents. All the fruits/seeds contained between 3.94 and 11.18 percent moisture, 26.67 and 89.92 percent carbohydrate and between 0.26 and 5.97 percent fat. Iron had a low concentration ranging from 36.43 to 117.83 $\mathrm{mg} / \mathrm{kg}$. Nickel and mercury were in trace amount in Dialium guineense and Aframomum melegueta. Calcium ranged from 0.06 to $2.56 \mathrm{mg} / 100 \mathrm{mg}$, magnesium ranged from 0.22 to $0.98 \mathrm{mg} / 100 \mathrm{mg}$, potassium ranged from 0.26 to $1.05 \mathrm{mg} / 100 \mathrm{mg}$, sodium ranged from 0.18 to $0.85 \mathrm{mg} / 100 \mathrm{mg}$ and phosphorus ranged from 0.14 to $0.76 \mathrm{mg} / 100 \mathrm{mg}$. The order of lead contents is as follows: Garcinia kola > Aramomum melegueta > Dialuim guineense > Dacryodes edulis > Gambeya albida. It was concluded that little quantity of Aframomum melegueta, Dialium guineense, Gambeya albida and Garcinia kola should be taken when the need arises as these contain reasonable amount of copper, zinc, lead and mercury. These metals could have adverse effects on the liver and kidney of the consumers when a large quantity is taken.
\end{abstract}

(c) 2012 International Formulae Group. All rights reserved.

Keywords: Proximate, phytochemical, adverse effects, lead, zinc, mercury.

\section{INTRODUCTION}

The tropical rainforest of Nigeria consists of a complex mixture of woody plant species of which 112 plant species have been enumerated per hectare at Omo Biosphere Reserve, (Dike, 1992). Most of these plants species produce flowers and fruits periodically. Efforts have been made to cultivate some of these edible fruits/seeds in compound farms (Okafor, 1981). Few of these fruits such as Aframomum melegueta are presented to visitors as a sign of hospitality during visits, feasts and ceremonies (Meregini, 2005). These visitors often consumed all or most parts of the edible parts of the gift in appreciation for their warm 
reception by their guests. It is assumed that these edible fruits/seeds which have been consumed for several years contain no elements that could cause harm to the consumer. It appears that some toxic elements although in small quantity could have cumulative adverse effects in the body of the consumer. Mercury could decay the liver of the individual. There is the need to analyze and find out the proximate, phytochemical and mineral compositions of each of these fruits/seeds often consumed by both the people living within the Nigerian rainforest and some of their visitors. A proper knowledge would highlight those that needed processing to reduce the level of the toxic elements in them. This paper reports the proximate, phytochemical and mineral compositions of five edible fruits/seeds of Nigerian rainforest.

\section{MATERIALS AND METHODS}

The study area was carried out at the University of Agriculture Umudike, Nigeria. Umudike lies between latitude $5^{0} 27^{\prime \prime}$ and $5^{0}$ 32 " $\mathrm{N}$ and longitudes $7^{0} 32^{\prime}$ and $7^{0} 35^{\prime \prime} \mathrm{E}$. The climate is of the equatorial type. The top soil temperature ranges between $16{ }^{\circ} \mathrm{C}$ and $45{ }^{\circ} \mathrm{C}$. There are two seasons: a wet and a dry season. The wet season starts from mid-March and ends in mid-November. The dry season continues till mid-March of the following year. The annual rainfall ranges between 1500 $\mathrm{mm}$ and $3000 \mathrm{~mm}$. The relative humidity is very high, ranging between 60 and 95 percent during the wet season. The relative humidity is especially high during the peak of rainfall in the month of June/July. A second peak in rainfall occurs in the month of September. The dry dusty Harmattan wind blows intermittently within the months of December and January. Within the Harmattan period, the relative humidity is very high but rain rarely falls. The temperature is also lower than the annual mean temperature especially during the nights and early mornings. The vegetation is the tropical rainforest (Onochie, 1979). The original vegetation has been destroyed. Secondary forest regrowths in various degrees of degradation are seen in many places. The abundant tree species are mainly those that could survive after the slash and burn agricultural operations. Such tree species include Anthonotha macrophylla, Dactyladenia barteri, Dialium guineense, Elaeis guineensis, Napoleonaea vogelii and Pentaclethra macrophylla. The slope is qentle. There are no hills or mountains. The soil is deep and in many places without stones. The soil is sandy loam. The soil parent material is the pre-Cambrian Basement Complex.

\section{Methodology}

Ten fruit bearing individuals each of Aframomum melegueta, Dacryodes edulis, Dialium guineense, Gambeya albida and Garcinia kola were marked with numbered aluminum tags. From each plant species, ten fruits were collected and taken to the Ecological Centre of the University. The edible parts of each plant species were extracted and put into a labeled and numbered envelope. Each envelope was put into an oven set at $65{ }^{\circ} \mathrm{C}$ for 24 hours. Each sample was removed from the oven and put into a labeled sterile bottle from where a sample for analysis was collected for the proximate, phytochemical and mineral compositions according to the procedure of AOAC (2000).

\section{RESULTS AND DISCUSSION}

The edible parts of the fruits/seeds are listed in Table 1. It is only the seeds of Aframomum melegueta that is edible. In both Dialium guineense and Gambeya albida, the fruit mesocarp and endocarp are edible while the seeds are not edible. In Garcinia kola, both the fruit and seed or ectocarp are not edible. However, it is the seeds and not the 
fruits of Garcinia kola that are presented to visitors. The other remaining part of the fruits is used either for jam preparation when the need arises or is thrown away. Dacryodes edulis gave the highest moisture content while Dialium guineense had the least result. Aframomum melegueta had the highest percent ash content. The order of the ash contents were as follows: Aframomum melegueta > Garcinia kola > Gambeya albida > Dialium guineense > Dacryodes edulis (Table 2). The order of crude protein contents of the five species were as follows: Dacryodes edulis > Gambeya albida > Aframomum melegueta > Garcinia kola > Dialium guineense. Dialium guineense and Dacryodes edulis had the highest and least carbohydrate contents, respectively. Garcinia kola had the highest fat contents while Dacryodes edulis had the highest crude fibre contents.

The moisture (3.94-6.76\%), ash (2.63$8.00 \%)$, crude protein (1.31-11.20\%), crude fibre $(0.3-12.74 \%)$ and carbohydrates (26.67$89.92 \%$ ) obtained in the fruits and seeds of the five plant species are within the ranges reported by Williams (1993) and Dike (2010).

The order of the plant species alkaloid contents ranged as follows: Aframomum melegueta > Dialium guineense > Garcinia kola,> Gambeya albida,> Dacryodes edulis. Dialium guineenese and Aframomum melegueta have the higher flavonoid contents than those of the other three species. Gambeya albida and Dialium guineense gave the highest and least saponin contents, respectively. The order of the species phytate contents were as follows: Garcinia kola > Aframomum melegueta > Dacryodes edulis > Dialium guineense > Gambeya albida (Table $2)$. The saponin $(0.20-1.18 \%)$, phytate $(0.06-$ $0.63 \%)$, alkaloids $(0.14-2.99 \%)$, and flavoniod $(0.16-10.64 \%)$ of the plants species were within the acceptable limit for edible fruits and seeds (Kumar, 1992; Williams, 1993).

Aframomum melegueta and Dacryodes edulis had the highest and least calcium contents while Garcinia kola and Dacryodes edulis gave the highest and least magnesium contents. The order of iron contents is as follows: Garcinia kola > A. melegueta > D. guineense > D. edulis > G. albida. Dialium guineense and Garcinia kola had the highest and least zinc content. The order of zinc contents is as follows: Dialium guineense $>G$. albida $>$ A. melegueta $>$ D. edulis $>$ G. Kola . Lead, chromium, zinc and iron were present in the edible parts of the fruits/seeds. The order of lead contents is as follows: Garcinia kola > A. melegueta $>$ D. guineense $>$ D. edulis $>G$. albida. Lead poisoning could damage the kidney and affect the nervous system and the reproductive system. Copper could affect the liver and kidney when a high dose is taken.

Table 1: Edible parts of fruits/seeds of five plant species from Nigerian rainforest.

\begin{tabular}{ll}
\hline Species & Edible parts of fruits/seeds \\
\hline Gambeya albida & Fruit endocarp and mesocarp \\
Dialium guineense & Fruit endocarp and mesocarp \\
Dacryodes edulis & Fruit endocarp and mesocarp \\
Aframomum melegueta & Entire seed \\
Garcinia kola & Seed endocarp and mesocarp \\
\hline
\end{tabular}


M.C. DIKE and E. AHAMEFULA NNAMDI / Int. J. Biol. Chem. Sci. 6(4): 1905-1909, 2012

Table 2: Proximate, phytochemical and mineral compositions of edible parts of fruits/seeds of five woody plants species studied at Umudike, Nigeria.

\begin{tabular}{|c|c|c|c|c|c|}
\hline \multirow[t]{2}{*}{ Parameters } & Sapotaceae & Caesalpinioideae & Burseraceae & Zingiberaceae & Guttiferae \\
\hline & Gambeya albida & Dialium guineense & Dacryodes edulis & Aframomum melegueta & Garcinia kola \\
\hline Moisture content (\%) & $11.20-11.16(11.18)$ & $3.92-3.96(3.94)$ & $7.28-6.24(6.76)$ & $5.60-5.64(5.62)$ & $6.10-6.22(6.16)$ \\
\hline Crude protein $(\%)$ & $9.63-9.19(9.41)$ & $1.75-1.87(1.81)$ & $11.20-11.20(11.20)$ & $8.31-9.19(8.75)$ & $5.19-5.75(5.47)$ \\
\hline Fat $(\%)$ & $1.38-1.35(1.365)$ & $0.32-0.40(0.36)$ & $0.27-0.25(0.26)$ & $0.96-1.04(1.00)$ & $5.89-6.04(5.965)$ \\
\hline Crude fibre (\%) & $0.28-0.32(0.3)$ & $0.84-0.92(0.88)$ & $13.20-12.28(12.74)$ & $7.20-6.88(7.04)$ & $5.42-5.50(5.46)$ \\
\hline Ash (\%) & $5.40-5.16(5.28)$ & $3.88-4.02(3.95)$ & $2.16-3.10(2.63)$ & $8.24-7.76(8.00)$ & $6.28-6.64(6.46)$ \\
\hline Carbohydrate (\%) & $74.40-73.26(73.83)$ & $89.44-90.40(89.92)$ & $27.23-26.11(26.67)$ & $71.08-70.10(70.59)$ & $80.3-79.6(79.95)$ \\
\hline Alkaloid(\%) & $0.360-0.360(0.36)$ & $1.96-2.12(2.04)$ & $0.14-0.14(0.14)$ & $2.82-2.76(2.79)$ & $0.62-0.60(0.61)$ \\
\hline Saponnin $(\%)$ & $1.16-1.19(1.175)$ & $0.21-0.19(0.20)$ & $0.16-0.16(0.16)$ & $0.48-0.54(0.51)$ & $0.41-039(0.4)$ \\
\hline Flavonoid(\%) & $0.38-0.41(0.395)$ & $10.22-11.06(10.64)$ & $0.30-0.34(0.32)$ & $8.94-9.01(8.975)$ & $0.49-0.54(0.515)$ \\
\hline $\mathrm{HCN}(\mathrm{mg} / \mathrm{kg})$ & $0.110-0.105(0.105)$ & $0.12-0.12(0.120)$ & $0.32-0.32(0.32)$ & $0.45-0.48(0.465)$ & $0.490-0.646(0.563)$ \\
\hline Tannin(\%) & $0.128-0.086(0.107)$ & $0.052-0.055(0.0535)$ & $0.26-0.22(0.24)$ & $0.44-0.43(0.435)$ & $0.480-0.646(0.563)$ \\
\hline Phytate & $0.066-0.058(0.062)$ & $0.080-0.110(0.095)$ & $0.24-0.24(0.24)$ & $0.36-0.42(0.39)$ & $0.628-0.640(0.634)$ \\
\hline $\mathrm{Ca}(\mathrm{mg} / 100 \mathrm{mg})$ & $0.901-1.10(1.002)$ & $1.406-1.405(1.4055)$ & $0.07-0.05(0.06)$ & $2.51-2.61(2.56)$ & $2.11-2.41(2.26)$ \\
\hline $\mathrm{Mg}(\mathrm{mg} / 100 \mathrm{mg})$ & $0.304-0.365(0.335)$ & $0.547-0.486(0.5165)$ & $0.22-0.22(0.22)$ & $0.851-0.790(0.821)$ & $0.973-0.973(0.975)$ \\
\hline $\mathrm{K}(\mathrm{mg} / 100 \mathrm{mg})$ & $0.40-0.50(0.45)$ & $0.700-0.625(0.6625)$ & $0.25-0.27(0.26)$ & $0.525-0.575(0.55)$ & $1.075-1.025(1.05)$ \\
\hline $\mathrm{Na}(\mathrm{mg} / 100 \mathrm{mg})$ & $0.325-0.375(0.35)$ & $0.475-0.475(0.475)$ & $0.20-0.16(0.18)$ & $0.225-0.175(0.2)$ & $0.775-0.925(0.85)$ \\
\hline $\mathrm{P}(\mathrm{mg} / 100 \mathrm{mg})$ & $0.700-0.700(0.7)$ & $0.775-0.750(0.7625)$ & $0.14-0.14(0.140)$ & $0.550-0.526(0.538)$ & $0.750-0.725(0.738)$ \\
\hline $\mathrm{Zn}(\mathrm{mg} / \mathrm{kg})$ & $103.20-103.16(103.18)$ & $138.25-140.25(139.25)$ & - & $97.00-94.50(95.75)$ & $25.15-26.33(25.74)$ \\
\hline $\mathrm{Co}(\mathrm{mg} / \mathrm{kg})$ & $6.80-7.05(6.925)$ & $13.50-13.50(13.50)$ & $6.20-5.26(5.73)$ & $7.00-8.25(7.625)$ & $21.60-20.95(21.275)$ \\
\hline $\mathrm{Cu}(\mathrm{mg} / \mathrm{kg})$ & - & $36.25-33.50(34.875)$ & - & $47.25-46.25(46.75)$ & - \\
\hline $\mathrm{Ni}(\mathrm{mg} / \mathrm{kg})$ & Trace & Trace & Trace & Trace & $3.14-3.11(3.125)$ \\
\hline $\mathrm{Pb}(\mathrm{mg} / \mathrm{kg})$ & $0.56-0.58(0.57)$ & $0.75-0.80(0.775)$ & $0.04-0.04(0.04)$ & $3.00-2.25(2.265)$ & $11.60-11.80(11.7)$ \\
\hline $\mathrm{Hg}(\mathrm{mg} / \mathrm{kg})$ & $0.01-0.01(0.01)$ & Trace & $0.01-0.01(0.01)$ & 0.25 -Trace & $0.01-0.01(0.01)$ \\
\hline
\end{tabular}




\section{Conclusion}

The entire elements tested were present in the edible parts of the seeds. Some of these elements such as lead, chromium, zinc and iron are likely to have cumulative adverse effects on the consumer. It is recommended that large quantities of these fruits/seeds should not be consumed. Moreover, Universities and industries should prepare jam from these fruits/seeds and reduce the toxic element in the jam before marketing them.

\section{REFERENCES}

AOAC. 2000. Official Methods of Analysis International. $\left(17^{\text {th }}\right.$ edn). Association of Official Analytical Chemists: Washington D.C, U.S.A.

Dike MC. 1992. Tree regeneration, recruitment and mortality in Nigeria tropical moist forests. Ph.D Thesis. University of Ibadan. Ibadan, Nigeria, p. 245.

Dike MC. 2010. Proximate, Photochemical and Nutrient compositions of some fruits, seeds and leaves of some plant species at Umudike, Nigeria. ARPN Journal of
Agricultural and Biological Science, 507: 7-16.

Kumar R. 1992. Anti-nutritional factors. The potential risks of toxicity and methods of alliating them. Legume Trees and Shrubs as Protein Sources for Livestock. Speedy AW, Pugliese P (eds). Proceedings of the FAO Expert Consultation held at MARDI in Kuala Lumpur, Malaysia, 14-18 October 1991.

Meregini AOA. 2005. Some endangered plants producing edible fruits and seeds in southeastern Nigeria. Fruit, 60: 211-220.

Okafor JC. 1981. Edible indigenous woody plants in the rural economy of the Nigerian forest zone. Forest Ecology and Management, 3: 48-55.

Onochie. 1979. The rainforest Ecosystem-An Overview. In The Nigerian Rainforest Ecosystem. Okali DUU (ed). Federal Ministry of Science and Technology MAB, Ibadan Nigeria; 1-13.

Williams JT. 1993. Introduction underutilize pulse and vegetable. In Pulses and Vegetables, Williams JT (ed) Chapman and Hall Inc.: New York, USA; 1-9. 